\title{
Remembering Australian Prisoners of War: Memory and Mourning at the Changi Chapel Memorial
}

\author{
Davina French
}

'Their bodies are buried in peace; but their name liveth for evermore' Ecclesiasticus 44:14

\section{Abstract}

The Changi Chapel was constructed by Australian servicemen in the World War II prisoner of war (POW) camp at Changi in Singapore. At the end of the war it was dismantled and shipped to Australia, where it now stands in the grounds of the Royal Military College, Duntroon. In 1988 it was dedicated as the National Prisoner of War Memorial. Despite the centrality of Changi and the Thai-Burma Railway in Australian collective memory, and the role of the POW experience in bolstering the narrative of 'mateship' that underpins national identity, the Chapel has not gained the prominence in public discourse of its larger neighbour, the Australian War Memorial. In this paper the current uses and meaning of the Chapel are examined. Its role in public ritual is contrasted with unique evidence of its meaning for personal commemoration, drawn from an informal Visitors' Book at the site. Through analysis of this evidence and comparison with other relevant sites, the Chapel is shown to be primarily a site of personal remembrance, which is often an enactment of mourning. The naming of the dead emerges as a key to understanding the nature of this kind of war remembrance.

The 'war memory boom' of the past two decades is now a commonplace in historical and political analysis. ${ }^{1}$ It has been accounted for by factors ranging from State-driven attempts to redefine national identity in the post-Cold War era to concerns that the war-time generations would pass without their stories being heard. ${ }^{2}$ Jay Winter also argues for a new 'market' for memory among consumers with more education, income and leisure-time than previous generations. ${ }^{3}$ In

\footnotetext{
1 For example, Duncan Bell, ed. Memory, Trauma and World Politics, (Basingstoke, Hampshire: Palgrave Macmillan, 2006); Jay Winter, War Remembrance, (New Haven: Yale University Press, 2006); T.G. Ashplant, G. Dawson and M. Roper, eds. The Politics of War: Memory and Commemoration, (London: Routledge, 2000). 2 Joan Beaumont, 'Prisoners of War in Australian National Memory' in Prisoners of War, Prisoners of Peace, eds. B. Moore and B. Hately-Broad (Oxford: Berg, 2005), 192.

3 Jay Winter, 'Notes on the Memory Boom: War, Remembrance and the Uses of the Past', in Memory, Trauma and World Politics, ed. Duncan Bell (Basingstoke, Hampshire: Palgrave Macmillan, 2006) 68.
} 
the Australian public sphere this has resulted in increased attendance on Anzac and Remembrance Day, a rash of new monuments and a burgeoning industry providing tours of significant battlefield sites. ${ }^{4}$

Historians and popular authors alike have ridden this wave of public interest. As well as books offering new histories of Australia's involvement in the wars of the twentieth century, studies of war commemoration have been prominent. ${ }^{5}$ These often draw upon the notion of 'sites of memory'; locations where memories of an event are recalled, selected and shaped into a shared understanding of the past. Such sites include original locations, such as battlefields, but also war memorials and museums. ${ }^{6}$

War memorials and battlefield cemeteries have received particular attention since they can serve two functions: supporting the personal commemoration and mourning of veterans and their families, and providing a location for national collective remembrance. Winter suggests that personal commemoration is associated with early post-war years, when these sites provide 'a framework for and legitimation of individual and family grief. ${ }^{7}$ He sketches a pattern in which, as time passes and the pain of bereavement subsides, collective uses take over and serve increasingly nationalistic ends. ${ }^{8}$ When Bruce Scates described modern uses of World War I battlefields and cemeteries he also saw a combination of the personal and the collective. He observed pilgrims of the 1990s still seeking the graves of their grandfathers and touching their names in a ritual of mourning that Winter locates in the 1920s. ${ }^{9}$ Alongside them, however, Scates saw a generation of Australian youth, educated in the values of the 'Anzac Legend', who stop off on the backpacker trail to learn 'what it means to be Australian'. ${ }^{10}$ In Scates' survey, individual mourning was joined, rather than replaced, by collective rituals of national pride.

4 Preface in Marilyn Lake and Henry Reynolds, eds. What's Wrong with Anzac? The Militarisation of Australian History, (Sydney: University of New South Wales Press, 2010), vii. Subsequent to the publication of Lake and Reynold's book, a new memorial to Australia's National Servicemen was dedicated at AWM on 8 Sept. 2010.

5 For example, in the Australian context, Ken Inglis, Sacred Places: War Memorials in the Australian Landscape. (Melbourne: Miegunyah Press, 1998); Liz Reed, Bigger than Gallipoli: War, History, and Memory in Australia. (Perth: University of Western Australia Press, 2004); Bruce Scates, Return to Gallipoli: Walking the Battlefields of the Great War, (Cambridge: Cambridge University Press, 2006).

6 Pierre Nora, 'Between Memory and History: Les Lieux de Mémoire', Representations 26 (1989): 12.

7 Jay Winter, Sites of Memory, Sites of Mourning: The Great War in European Cultural History, (Cambridge: Cambridge University Press, 1995) 93.

8 Ibid., 98.

9 Scates, Return to Gallipoli, 107-108; Winter, Sites of Memory, 115.

10 Scates, Return to Gallipoli, preface. The Anzac Legend dates from the World War I dispatches and Official History of C.E.W. Bean. He described the Australian soldier, later to be known as the 'digger', as courageous and resourceful, with a dry wit and a healthy disregard for authority. The Legend however is more than the men; it has come to encompass the spirit and values of a nation, especially focused on toughness in adversity and the bond between fellow Australians known as 'mateship'. Perhaps most critically, it is about ordinary 
This paper focuses upon a unique site of memory from World War II, seeking evidence for these dual forms of remembrance in the context of a later conflict. World War II seldom rivals Gallipoli in national memory, but the Pacific campaigns have recently gained traction, for example through re-envisioning the period following the Fall of Singapore as the 'Battle for Australia'. ${ }^{11}$ The Kokoda Track has become a focal point for pilgrimage and for politicians seeking to redirect national identity away from Britain and Europe. Hank Nelson refers to these political efforts to refocus attention onto the Pacific region as attempts to 'bring the legend home'. ${ }^{12}$ Nelson also observed that 'the values that Australians might aspire to hold' run 'from Eureka to Gallipoli to Changi and Kokoda'; Changi has become another watchword in the inventory of nation-defining military episodes. ${ }^{13}$ This is at first surprising - even in comparison with Gallipoli, the suffering of Prisoners of War (POWs) held by the Japanese is a challenging narrative for reflection on Australian nationhood. But, as Joan Beaumont points out, the fact that almost half of those who died in the Pacific campaign died in Japanese captivity renders their stories salient. ${ }^{14}$ Their experiences as POWs, and the ways in which they are remembered, have therefore become subjects of considerable study. ${ }^{15}$ One further facet of POW remembrance is considered here through examining Australia's first National Prisoner of War Memorial.

When Singapore fell to Japan in February 1942 over 45,000 Allied servicemen were taken prisoner and held at Changi barracks in Singapore and more than 132,000 personnel from six nations were captured by the war's end. Many were sent to locations such as the Thai-Burma Railway, but those who survived returned to Changi. ${ }^{16}$ In May 1944 they were moved to Changi Prison, a civilian prison complex much too small for them, where they remained until liberation fifteen months later. During this time food and medical supplies were much reduced and their physical health deteriorated markedly, although at no stage

men, 'other ranks', rather than the warrior-heroes of classical legend, and has progressively incorporated into its narrative a belief that Britain, as much as Turkey, Germany or Japan, was implicated in Australia's military defeats.

11 As recently as 2008 Australia gained a new 'day', with 'Battle for Australia Day' being marked on the first Wednesday of September each year, Alan Griffin, Battle for Australia Day to be marked across Australia, Media Release, Aug. 31 2008. http://minister.dva.gov.au/media_releases/2008/08_aug/VA085.pdf (accessed October 12 2010). Even before this however, the extent to which the battle was really one to prevent the invasion of the Australian homeland was hotly contested, see for example Peter Stanley, Invading Australia: Japan and the Battle for Australia, 1942 (Camberwell, Vic.: Viking, 2008).

12 Hank Nelson, 'Gallipoli, Kokoda and the Making of National Identity', Journal of Australian Studies 21 (1997): 164.

13 Hank Nelson, 'Kokoda: The Track from History to Politics' The Journal of Pacific History, 38 (2003): 110.

14 Beaumont, 'Prisoners of War in Australian National Memory', 186.

15 For example, Kevin Blackburn, 'Changi: A Place of Personal Pilgrimages and Collective Histories' Australian Historical Studies 112 (1999): 153-73; Annette Hamilton, 'Skeletons of Empire: Australians and the Thai-Burma Railway', in Memory and History in Twentieth-Century Australia, eds. Kate Darian-Smith and Paula Hamilton, (Oxford: Oxford University Press, 1994), 92-112.

16 Of the 22,000 Australians captured, around 13,000 worked on the Thai-Burma railway and more than 8,000 (more than one third) did not survive; 'Appendices' in Hank Nelson and Gavan McCormack, eds. The Burma-Thailand Railway: Memory and History, (Sydney: Allen and Unwin, 1993) 160-162. 
were death rates comparable to those on the Railway. ${ }^{17}$ Since almost all POWs spent time at Changi, its name has become 'an evocative summary' of the experiences of all prisoners of the Japanese. ${ }^{18}$ In this light, it is perhaps not surprising that a relic of Changi should make its way to Australia to serve as a focus for remembrance.

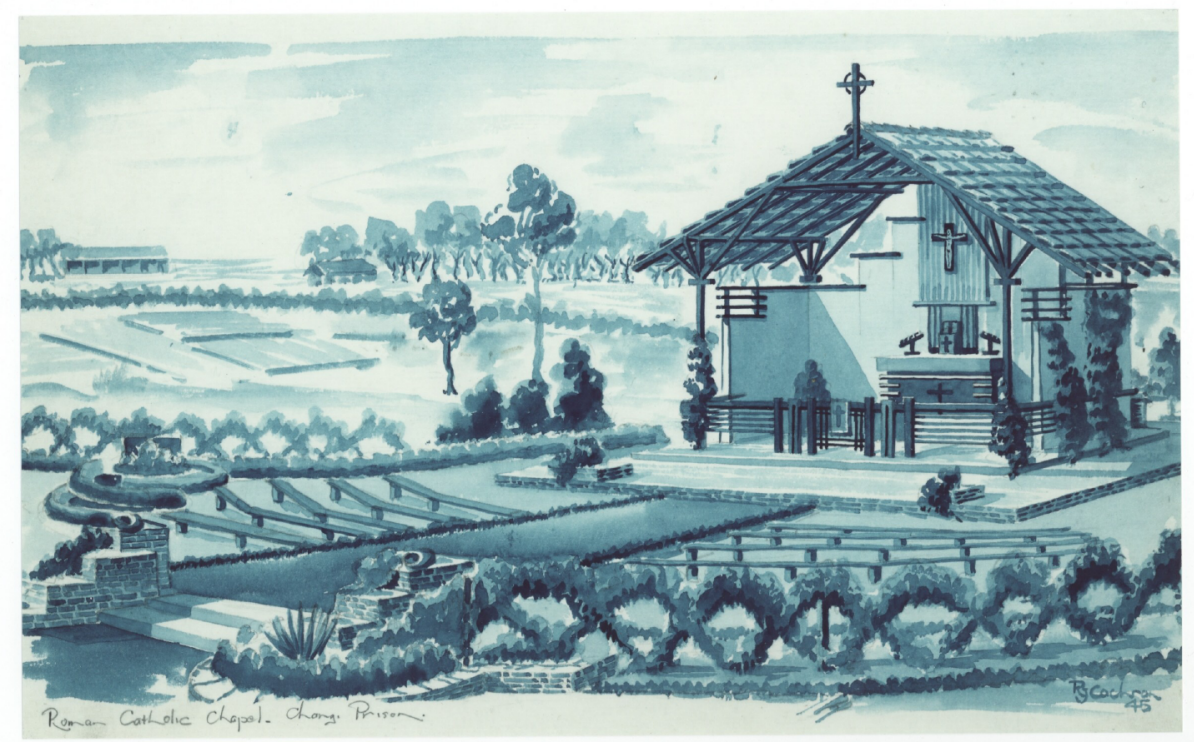

\section{The Chapel at Changi Gaol, painted by a POW in $1945^{19}$}

The Changi Chapel was built as 'Our Lady of Christians Roman Catholic Chapel' by POWs in the grounds of the prison, at the request of Army Chaplain Father Lionel Marsden. It was one of thirteen chapels at the prison and evolved from a simple palm-thatched structure to its present design during the final fifteen months of the POWs' captivity. ${ }^{20}$ Many of its features, such as the altar and front railings, are decorative as well as functional; its design and construction still attest to the care and commitment of its original builders. It originally bore

17 R.P.W. Havers, Reassessing the Japanese Prisoner of War Experience: the Changi POW Camp, Singapore, 1942-5, (London: Routledge Curzon, 2003) 10-11, 137, 154, 171.

18 Hank Nelson, 'Beyond Slogans: Assessing the Experiences and the History of Australian Prisoners of War of the Japanese', in Forgotten captives in Japanese Occupied Asia, eds. Karl Hack and Kevin Blackburn. (Oxford : Routledge, 2008), 31.

19 Richard Cochran, Roman Catholic Chapel, Changi Prison, 1945, Australian War Memorial item no. ART28914. All efforts were made to identify the owner of copyright for this image, however none was identified; fair use is claimed for not-for-profit educational \& scholarship purposes.

20 Australian Construction Authority, Report on the Reconstruction of Changi Chapel as a National Prisoner of War Memorial, 12. Canberra, 1989. Australian War Memorial Records Collection, PR91/041; Steve Hart, Duntroon: its Heritage and Sacred Legacy. (Canberra: Defence Publishing Service, 2009), 38. 
the dedication 'in memory of our deceased comrades...over whose remains there was no Christian symbol'; it was from the beginning a memorial as well as a place for Roman Catholic worship. ${ }^{21}$

Following the Japanese surrender, Corporal Max Lee, working with the Commonwealth War Graves Commission, gained permission to dismantle the Chapel and have it shipped to Australia for display at the Australian War Memorial (AWM). ${ }^{22}$ The crates were stored until 1985, when it was offered to the Army Museum on the grounds that it was too large for the AWM. ${ }^{23}$ Recent commentators have suggested that this surface reading of the contemporary documents may be naive, and that the search for an alternative to the AWM may rather reflect tension between POW memory and traditional 'Anzac' values. ${ }^{24}$

The Army History Unit determined that the Chapel was too significant to be consigned to one of its own museums and consulted the veterans associations. ${ }^{25}$ With the support of the Returned Services League and the Ex-POWs Association it was reconstructed at the Royal Military College (RMC), Duntroon as a National Memorial to Australian POWs. Corporal Lee's meticulous notes and photographs, along with his involvement in the reconstruction, have ensured that the reconstructed Chapel is almost identical to the original. In bureaucratic terms, it is now the responsibility of the National Capital Authority and is treated as one of the set of memorials otherwise located on Anzac Parade. ${ }^{26}$

As a war memorial, the Chapel is unique. In the aftermath of World War I most commemorative sites were carefully designed monuments; more than ninety per cent bore an honour roll. ${ }^{27}$ For Winter, it is a fundamental component of these memorials that they honour the dead by naming them, ${ }^{28}$ although Australian memorials often differ from European ones by also naming those who returned. ${ }^{29}$

\footnotetext{
21 Father Lionel Marsden, 'Australia's Lost Division', The Catholic Weekly, November 15 1945, 21. This article was tabled at a meeting of the National POW Memorial Trust Committee, but not archived with the minutes, ARMCD, Changi Chapel Box 1, Minutes of the National POW Memorial Trust September 17 1987, item 14.

22 'Changi Chapel to go into Museum' in The Telegraph, Brisbane, 1st July 1946. ARMCD, Changi Chapel Box 1, CE/R985/1/18/1, folio 10.

23 Minutes of the Changi POW Chapel Project Committee, 11th February 1987. ARMCD, Changi Chapel Box 1, CE/R985/1/18/1, folio 18 .

24 Lachlan Grant, 'What makes a 'National' War Memorial? The Case of the Australian Ex-POWs Memorial', Public History Review 12 (2006): 93.

25 Brigadier M.P. Blake, 'Letter to the Commandant, Royal Military College, Duntroon', December 51985. ARMCD, Changi Chapel Box 2, letter originally referenced A85 - 36972.

26 For example, in response to a request to place individual regimental plaques in the Chapel the Trustees note that 'It appears that none of the other National Memorials on ANZAC Parade have ... individual memorials attached to them.' Agenda Paper for a Special General Meeting of the National POW Memorial Trust - 12 June 1991, item 6. ARMCD, Changi Chapel Box 1, Minutes of the National POW Memorial Trust, originally referenced A88-36250.

27 Inglis, Sacred Places, 144, 180.

28 Winter, Sites of Memory, 98.

29 Inglis, Sacred Places, 181.
} 
Following World War II, more functional memorials, such as halls, parks and swimming pools, were commonly selected, but the names of the fallen were also added to the earlier monuments, ${ }^{30}$ a permanent indictment that the Great War did not 'end all wars'.

These stone memorials are still an important focus for national and local commemoration, as witnessed by the increased attendance at Anzac Day services and the erection of new memorials discussed above. But Australians also now travel the globe to visit historic battlefield sites, such as the Kokoda Track and the Gallipoli peninsula. These incorporate their own cemeteries and memorials, which also provide the focus for collective rituals such as the Anzac Day dawn service. Observers have argued that the authenticity of these landscapes lends particular poignancy to the individual reflections that take place there. ${ }^{31}$

The Changi Chapel echoes both kinds of commemorative site: the monument and the battlefield; but it is not quite either. It is a National Prisoner of War Memorial, but it bears no honour roll. This is likely due to its grouping with the memorials on Anzac Parade; none bears the names of those it commemorates. ${ }^{32}$ Nevertheless, all of the others are within a short walk of the Roll of Honour at the AWM itself, and like the cemeteries of the Western Front, the AWM bears the dedication 'Their name liveth for evermore'.

Most of the memorials on Anzac Parade are rich in symbolism, and their messages have become more complex with each new addition. By contrast, if the Chapel has meaning, it is derived through authenticity; nothing has been added to the original building of 'scrap wood and metal'33 beyond two brass plaques. One provides a brief history of the Chapel and describes it as 'an act of enduring faith in the midst of extreme adversity'. The other lists the conflicts in which Australian POWs were taken, and records, in typically democratic fashion, that it was unveiled by 'a former prisoner of war'. Its untouched quality resembles a historic site, although its relocation to Canberra has led some to question its authenticity. ${ }^{34}$ Its very simplicity may, however, provide new insight into the ways in which Australians interact with their memories at this and other significant sites of war commemoration.

\footnotetext{
30 Inglis, Sacred Places, 352.

31 For example, Scates, Return to Gallipoli, 189, quotes a visitor observing the young backpackers clambering over the ridges of Lone Pine and thinking that 'they could so easily have been the Anzac troops of $1915^{\prime}$

32 The Vietnam Forces National Memorial does, in fact, contain the names of those who died, but they are written on a scroll that is sealed into the stone, where they cannot be seen or touched. 


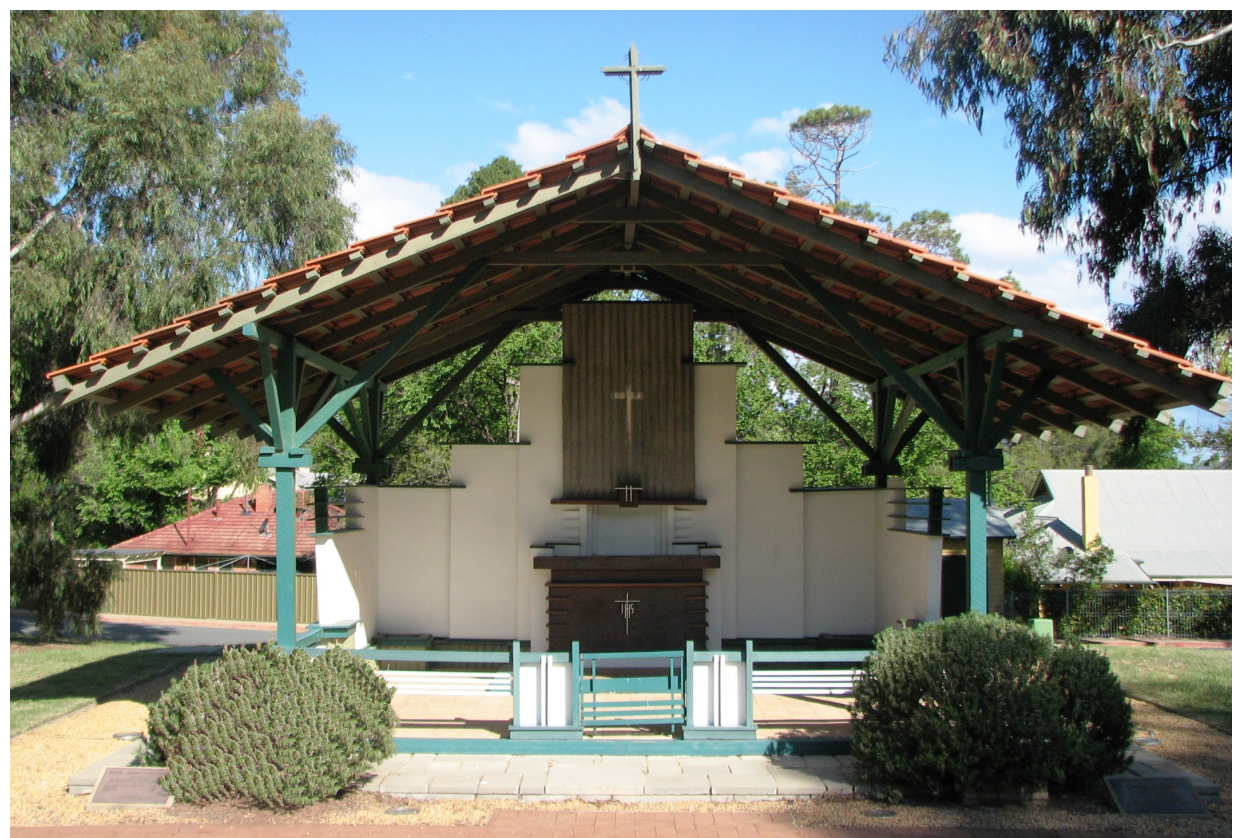

The Chapel in its new location at RMC Duntroon.

The first public use of the Changi Chapel was its dedication on Victory in the Pacific (VP) Day (August 15 ${ }^{\text {th }}$ ), 1988; in this it already drew upon established World War II memory. The dedication plaque was unveiled by Sir Edward (Weary) Dunlop, a surgeon in Changi, and the lesson read by Mrs. Vivian Statham (née Bullwinkel), the only survivor of a Japanese massacre of prisoners on Bangka Island, off Sumatra, in 1942. In the Australian narrative these two names are more closely linked with Japanese captivity than any others. Sir Edward's speech also made links to the broader narrative of Anzac by urging those present to 'create a national spirit which will be worthy of the selflessness and sacrifice which is enshrined in the Chapel. ${ }^{35}$ The signs from this initial service were that the Chapel would take its place within the established Anzac framework.

The Chapel has seldom received public or media attention since that opening ceremony. Blackburn refers to visits by Singaporean politicians in the 1990s but they are only recorded in Singaporean sources, ${ }^{36}$ and the Duntroon Archives record only four additional services in 22 years. In 1989 a mass was celebrated to honour the Chapel's original builders, who had been located too late for them to attend the dedication ceremony. ${ }^{37}$ In February 1995 a two-day ceremony

35 Sir Edward Dunlop, 'Transcript of Speech at the Dedication of Changi Chapel as a National Memorial Remembering Prisoners of War', August 15 1988, ARMCD, Changi Chapel Box 2.

36 Blackburn, 'Changi', 163, referenced to the Straits Times.

37 Karen Hobson, 'ACT Reunion with a Changi Chapel', Canberra Times, March 18 1989, ARMCD, Changi Chapel Box 2. 
commemorated the anniversary of the Fall of Singapore as part of the larger Australia Remembers celebrations. It began with a service at the Chapel, but was followed the next day by a much larger ceremony at the AWM addressed by the Prime Minister Paul Keating. Twelve hundred ex-POWs and their families attended; these numbers could not possibly have been accommodated at the Chapel site. ${ }^{38}$ The speeches were short, but dense with the language of mateship and suffering; the Chapel was not mentioned. ${ }^{39}$

Two further services were held at the Chapel, one on Remembrance Day 1991 to remember Nurse POWs, and another on VP Day 2003 honouring the Army Chaplains who provided spiritual support to Australian troops during their captivity. ${ }^{40}$ Since no further adornments were permitted on the Chapel, the associated plaques are located in the grounds. The Committee of Trustees has since received several further requests to place commemorative markers in or around the Chapel, for example regimental plaques, dedications to particular saints and requests to scatter veterans' ashes; all have been refused. ${ }^{41}$ While other services may have taken place at the Chapel, it is perhaps ironic that the only one to leave a trace in the Canberra Times is a service for Vietnam veterans in $2002^{42}$ - no Australian POWs were taken in Vietnam. ${ }^{43}$ The evidence is sparse, but supports Blackburn's assertion that the site has not become a focus for collective remembrance of Australia's POWs. ${ }^{44}$

If public ritual leaves incomplete evidence, private remembrance is even more ephemeral. It is impossible to estimate how many visitors have stopped at the Chapel, whether they arrived in groups or alone, or how they remembered Australia's POWs. A formal book of remembrance has never been provided, so the reflections of a generation of visitors are lost. ${ }^{45}$ In the last two years however, fragments of memory have remained at the site. In May 2008 an Army Cadet Officer visiting from Western Australia was moved to leave his name. He was apparently carrying an A6-sized spiral bound notebook, the first eight pages

38 Australia Remembers was a year-long event intended to mark the 50th anniversary of the end of WW2. Attendance figure from Con Sciacca, Minister for Veterans Affairs, Australia Remembers the POW Story, Press Release, February 15 1995. Australian War Memorial, Souvenirs Collection 7, file 2/4/1, item 000884.

39 For example, Max Jagger (Federal President of the Ex-POW Association) used the term 'mate' or 'mateship' five times in a 600 word address. Australian War Memorial, Souvenirs Collection 7, file 2/4/1, item 000882.

40 Orders of service for these services available at ARMCD, Changi Chapel Box 2.

41 Agenda Paper for a Special General Meeting of the National POW Memorial Trust - 12 June 1991. ARMCD, Changi Chapel Box 1, Minutes of the National POW Memorial Trust, originally referenced A88-36250.

42 Roderick Campbell, 'Vietnam vets come to terms with service', Canberra Times, October 7 2002, http:// www.canberratimes.com.au/news/local/news/general/vietnam-vets-come-to-terms-with-service/514550. aspx ? storypage $=0$ (accessed September 20 2010).

43 Beaumont, 'Prisoners of War in Australian National Memory', 186.

44 Blackburn, 'Changi', 163.

45 Although Scates discusses entries in the visitors' books at Gallipoli and on the Western Front, he also notes that the Commonwealth War Graves Commission routinely destroys these books, so it seems that these memories are always fleeting, Return to Gallipoli, xxi. 
of which recorded the negative numbers of photographs taken on trips around Australia; he added his name and left the book inside the box that contained information leaflets about the Chapel.

In the intervening twenty-seven months around 100 entries were added, half of which are limited to names and dates. ${ }^{46}$ Some of these record visits by schools and groups of ex-servicemen, who often accompany their entry with the epitaph 'Lest We Forget'. But the remaining authors needed no such reminder; they have left overwhelmingly personal statements, rich with family memories. Eighty percent of these substantive entries name the soldier they are remembering; some give vivid details of places and events. These families seem proud, almost compelled, to leave enough information to identify the man they seek to honour. Examples given here are often edited since some are more than seventy words in length. ${ }^{47}$

Visited today in memory of my father [ ], returned prisoner of war, Changi. So very proud of my father's achievements and ability to overcome what he endured.

This is in memory of an uncle [] who was imprisoned in a room not more than $6^{\prime} \times 6^{\prime}$ with at least 6 men. He came back home to his family but struggled to settle in to normal life.

Visitors remember not only the POW experience, but the lifetimes of men who survived their captivity. Some overcame their experiences, but those who could not are also remembered.

Nelson has noted that a limitation of the Chapel as a National Prisoner of War Memorial is its close association with Japanese captivity, which may exclude or diminish other POW memories. ${ }^{48}$ Most entries do mention Changi or the ThaiBurma Railway, but one family remembered a father imprisoned in Germany while others remember 'the families of those who died in Vietnam' and 'the soldiers of today's army'. For some visitors this opportunity appears to provoke broader reflections on the cost of war.

When 'peace' was announced at the prison, the first thing my father did was walk to this chapel to thank God for his survival.

A number of entries make a direct link to the Chapel; they often express the hope that 'their' POW found some comfort there. Others, however, are far removed;

\footnotetext{
46 This research was undertaken in August 2010, with the last entry dated July 82010.

47 Visitors' Book, Changi Chapel, 2008-2010, facsimiles available on request. Despite the foregoing, I have chosen to omit names to preserve the privacy of those who left their memories; quotations contain empty square brackets where a name is omitted. In this informal setting grammar and punctuation are not always observed but I have not 'corrected' the quotes since the writer's meaning is generally clear.

48 Nelson, 'Beyond Slogans', 36.
} 
a family from Nambucca Heads remembered a son who trained at Duntroon and died on service in Germany in 1994. What characterises the large majority of entries is their deeply personal nature; families sign off with their love or address the deceased directly: 'You lived for those you loved, and those you loved will always remember'.

Some entries directly invoke the language of Anzac, echoing its dominant themes of mateship and sacrifice, for example 'Thank you [ ] and all your mates who died so we can enjoy freedom'. There are only eleven entries that remember POWs collectively, that is, without naming a relative or friend, and five of these use the terms 'sacrifice', 'suffering' or 'endurance'. But of the forty or more 'named' entries, only seven use terms commonly associated with public Anzac remembrance, and then they speak of bravery as often as sacrifice.

The Visitors' Book suggests that the Chapel has a particular role in helping families to remember their loved ones, rather than as a site for collective ritual. There have been few formal ceremonies held there, and when major national events have occurred, the Chapel site has been overshadowed by the main War Memorial. Furthermore, there is no evidence of entries clustering around significant dates such as Anzac or Remembrance Day. It does not appear that individuals or groups include the Chapel in an itinerary that starts with the dawn service or are prompted by media reminders that a significant anniversary is approaching.

This pattern of use differs somewhat from Scates' observations at Gallipoli, and diverges from what Winter might expect almost 70 years after the Fall of Singapore. Most messages are personal and individuated and some are resonant with mourning; at least six of the entries that remember a Changi survivor also mention his more recent passing. These often give a date of his death but there is no evidence that the visit was timed for such an anniversary. Winter describes mourners at war memorials as going 'beyond the limitations of place and time. ${ }^{49}$ Scates also noted that pilgrimage sites became a 'place outside time' where his informants experienced deeper connections to the past than they had been expecting. ${ }^{50}$ The timing of the visits is at least suggestive of the idea that the very personal experiences recorded in the Changi Chapel Visitors' Book also took some writers by surprise. They were not, however, lost for words and did not fall back upon the anonymous language of the Anzac Legend; instead they have created their own roll of honour, a book of personal tributes to loved ones whose experiences have shaped their family narratives.

In this respect, the location of the Memorial at RMC, Duntroon may also be significant. The Chapel is not the only site of remembrance in the college

49 Winter, Sites of Memory, 113.

50 Scates, Return to Gallipoli, for example 121. 
grounds; there are also several honour rolls and an extensive memorial space commemorating Duntroon graduates who have died in service. It is possible that some of the Chapel visitors who remembered a serviceman who was not a POW, or who died in a more recent conflict, had already found his name at these memorials. For them, the visit to Duntroon may have been something of a pilgrimage.

The uses of Changi Chapel can be further understood by drawing comparisons with other relevant sites, for example the original site of captivity in Singapore and the new Australian POW memorial in Ballarat. Blackburn's analysis of the original Changi prison site provides striking parallels with the evidence presented here. He described, in 1999, the meanings and uses of a site essentially created for the purpose of 'pilgrimage'. Other than the name, little of the original site was accessible to visitors - the chapel was a replica constructed outside the prison walls since the prison had resumed its penal function. There was also an interpretative museum, but Blackburn did not mention an honour roll. The messages left by visitors to the site were however strikingly similar to those found at Duntroon, and Blackburn also noted that 'many family members will make a pilgrimage to Changi a few years after their ex-POW family member has died. ${ }^{51}$ A number of the entries in the Duntroon Visitors' Book also suggest that the visit there was prompted by experiences at the Singapore site. One visitor even noted that 'After visiting Changi in Singapore I felt until I had been here to Duntroon to see the Chapel, my journey was not complete'.

The Ballarat memorial is a recent addition to Australia's commemorative sites; it was completed in 2004 and is a triumph of memorial symbolism. ${ }^{52}$ In the Australian tradition it names all 37,000 servicemen who became POWs across all wars, whether or not they returned. Its opening ceremony drew a crowd of 10,000 including 1,300 ex-POWs, ${ }^{53}$ challenging the idea that this group of veterans is now too physically or psychologically fragile to attend such events. Grant quotes the Federal Member of Parliament for Ballarat suggesting that

'in time our memorial will naturally progress to become a national memorial - a transition that will not seek to take away the significance of the Changi Chapel ... but in my view will naturally occur as people ... make the pilgrimage to the memorial here in Ballarat seeking names of people they have loved. ${ }^{\prime 54}$

\footnotetext{
51 Blackburn, Changi, 167.

52 Lachlan Grant, 'Monument and Ceremony: The Australian Ex-Prisoners of War Memorial and the Anzac Legend', in Forgotten captives in Japanese Occupied Asia, eds. Karl Hack and Kevin Blackburn, (Oxford: Routledge, 2008), 41-56.

53 Ibid., 54, Note 3.

54 Quoted in Grant, 'What makes a 'National' War Memorial?' 95, my emphasis.
} 
In 2008 the Ballarat Memorial was finally granted 'National status'; it was the first memorial outside Canberra to be so named and this required a change in Federal legislation. It followed an 'election commitment' in support of that same Member of Parliament, whose electorate was marginal in the 2007 Federal election. ${ }^{55}$ Grant describes a visit to the memorial by a Changi survivor who brought with him a list of fifty names to find; the significance of the honour roll at this site has clearly not been overlooked by commentators. ${ }^{56}$ Evidence from both sites suggests that, whatever ambivalence may have been apparent in the 1980s, POW remembrance is now both politically and emotionally powerful.

This examination of the Changi Chapel memorial provides a number of insights into the nature of Australian war remembrance. Ken Inglis has argued that in recent years the Anzac Legend has been stripped of its associations with fighting prowess, and has acquired "the vocabulary of sacrifice and victimhood". ${ }^{57}$ The experience of POWs in the Pacific theatre therefore epitomises the way that Australia now remembers its military past. This is also highlighted by the fact that the POW commemorations discussed earlier were used to launch the entire Australia Remembers year, ${ }^{58}$ and by the passions aroused by the recent redevelopment of the Changi Prison. ${ }^{59}$ The theme of the new narrative is, however, the supportive role of 'mates' and of medical personnel. Mateship is now a key theme for political uses of Anzac, ${ }^{60}$ and Sir Edward Dunlop is strongly represented in the grounds and exhibits of the AWM along with Simpson and his donkey. ${ }^{61}$ The role of Christian faith in this narrative is less clear; Inglis has described the Australian War Memorial as 'a temple of civil religion' and suggested that even non-denominational Christianity may be in tension with Anzac remembrance. ${ }^{62}$ The Changi Chapel's transition from a Roman Catholic place of worship to a non-denominational chapel, situated within the largely secular practice of remembering Australia's servicemen and women, may retain some of this tension.

55 Dominic Brine, 'Ballarat ex-PoW memorial gets national status', ABC local Radio, Ballarat, September 30 2008. http://www.abc.net.au/local/stories/2008/09/30/2378198.htm (accessed September 21 2010); Alan Griffin, Minister for Veterans' Affairs, Ballarat Ex-POW Memorial First to Benefit from New Legislation, Media Release, March 19 2008. http://minister.dva.gov.au/media_releases/2008/03_mar/VA024.pdf (accessed September 21 2010).

56 Lachlan Grant, 'Monument and Ceremony', 52.

57 Ken Inglis, "They Shall Not Grow Old", The Age, Melbourne, April 30th 2005, 8.

58 Sciacca, Australia Remembers the POW Story.

59 Joan Beaumont, 'Contested Trans-national Heritage: The Demolition of Changi Prison, Singapore', International Journal of Heritage Studies, 15 (2009): 288.

60 For example Prime Minister Keating referred to 'the bonds of mateship' when eulogizing the Unknown Soldier in November 1993, http://www.awm.gov.au/commemoration/keating.asp (accessed October 15 2010) and Nelson, 'Beyond Slogans', 32 quotes from Prime Minister Howard on Anzac Day 1998 valorizing the 'mateship, courage and compassion' of the Australian POWs.

61 Simpson was a stretcher bearer in WW1.

62 Inglis, Sacred Places, 459, 462. 
In broader terms the Chapel and its Visitors' Book provoke further enquiry into the role of naming in war remembrance. This brief survey of sites of Australian war commemoration suggests that the naming of the dead remains integral to their memory. Further evidence for this might be drawn from the history of the Chapel itself. Its original builder remembers hanging plaques naming four of his 'mates' who had died in captivity, but by 1946 they were gone, along with evidence of any other naming. ${ }^{63}$ The form of the Vietnam Memorial on Anzac Parade is also informative here; the names of the dead from that campaign are both present and invisible, inscribed on scrolls sealed into the stones, perhaps reflecting tension between AWM policy and the wishes of veterans.

The need of the living to name the dead is central to Winter's reading of war remembrance. It still appears to be as fundamental for the bereaved of World War II, Vietnam and even twenty-first century Manhattan ${ }^{64}$ as it was for his interpretation of World War I memorials. It may not, however, pass as quickly or completely as his analysis suggests. The Changi Chapel Visitors' Book demonstrates that those who seek to remember loved ones may render their names in many forms, and for many years. Touching a stone inscription or leaving a paper poppy are the common forms observed at the larger memorials and cemeteries, but in this intimate space where individuals must often be alone with their memories, they remember the POWs by recording their lives and achievements.

Analysis of their entries reveals a very private act for so public a space. This may reflect the nature of the site; it was described as a 'special and sacred place' by one of the visitors, and as 'serene but sombre' by another recent observer. ${ }^{65}$ Although its isolation from Anzac Parade may be an important factor in its relative lack of prominence, the quiet, tree-fringed site offers an atmosphere of peace that would be hard to replicate in the busier spaces of the War Memorial proper. This analysis also provides a reminder, however, that collective war memory in Australia is still contested space. The weight of evidence now suggests that the POW experience itself is not in tension with the contemporary construction of Anzac, ${ }^{66}$ but the Chapel's focus on faith and on the experience of a particular group of prisoners may have led to it being side-lined as a site for national, secular ritual. Beaumont has argued that war memorials become active sites of memory only when they are 'invested with a sacred quality by virtue of their association with battle' or when 'visitors can invest them with sacred

63 Hobson, 'ACT Reunion'.

64 The names of those who died on September 112001 have been read aloud at the site of the World Trade Centre every year on that date, and are now inscribed on a bronze memorial at ground zero.

65 Changi Chapel Visitors' Book, September 20 2008; Hart, Duntroon, 38.

66 Beaumont, 'Prisoners of War in Australian National Memory', 186. 
meaning through their private participation' ${ }^{67}$ The Changi Chapel appears to have retained its association with its original location, and both benefits from and contributes to the heritage of RMC, Duntroon. The evidence of the Visitors' Book also strongly attests to the meaningful participation of those who visit. Although the Changi Chapel has not been the scene of public ritual, it provides a unique opportunity to observe a different pattern of remembering, akin in some respects to Scates' Gallipoli pilgrimage, at a site of memory within Australia itself.

\section{Acknowledgements}

The author wishes to thank Ross Howarth for providing access to the Archives of the Royal Military College, Duntroon and for his assistance with several aspects of this research. I am also grateful to Joan Beaumont, Frank Bongiorno, Mark Dawson and Tristan Moss for their advice and encouragement during various stages of writing this paper.

67 Joan Beaumont, 'Australian Memory and the US Wartime Alliance: The Australian-American memorial and the Battle of the Coral Sea', War \& Society 22 (May 2004): 86. 